\title{
Ballistic protective properties of material representative of English civil war buff-coats and clothing
}

\author{
Brian May ${ }^{1} \cdot$ Richard Critchley $^{1}$ (D) $\cdot$ Debra Carr $^{1,2} \cdot$ Alan Peare $^{1} \cdot$ Keith Dowen $^{3}$
}

Received: 19 March 2020 / Accepted: 15 July 2020 / Published online: 21 July 2020

(C) The Author(s) 2020

\begin{abstract}
One type of clothing system used in the English Civil War, more common amongst cavalrymen than infantrymen, was the linen shirt, wool waistcoat and buff-coat. Ballistic testing was conducted to estimate the velocity at which $50 \%$ of 12-bore lead spherical projectiles $\left(V_{50}\right)$ would be expected to perforate this clothing system when mounted on gelatine (a tissue simulant used in wound ballistic studies). An estimated six-shot $V_{50}$ for the clothing system was calculated as $102 \mathrm{~m} / \mathrm{s}$. The distance at which the projectile would have decelerated from the muzzle of the weapon to this velocity in free flight was triple the recognised effective range of weapons of the era suggesting that the clothing system would provide limited protection for the wearer. The estimated $V_{50}$ was also compared with recorded bounce-and-roll data; this suggested that the clothing system could provide some protection to the wearer from ricochets. Finally, potential wounding behind the clothing system was investigated; the results compared favourably with seventeenth century medical writings.
\end{abstract}

Keywords Leather $\cdot$ Linen $\cdot$ Wool $\cdot$ Behind armour blunt trauma $\cdot$ Pencilling $\cdot 12$-bore

\section{Introduction}

At the end of the seventeenth century English Civil Wars, many survivors of Alexander Popham's Parliamentary Forces marched home to Littlecote (Wiltshire, UK), laid aside their weapons and armour and returned to their peacetime occupations [3]. Considered to be the last surviving Civil War armoury in Britain, the Littlecote House collection appears to have largely been assembled by Alexander Popham in the mid-seventeenth century [24] and was acquired by The Royal Armouries in 1985 [23]. Amongst the collection were 36 buff-coats [3] which form the largest single surviving group of such items in the world [23].

Richard Critchley

r.critchley@ cranfield.ac.uk

1 Centre for Defence Engineering, Cranfield University, Defence Academy of the United Kingdom, Shrivenham SN6 8LA, UK

2 Defence and Security Accelerator, Porton Down, Wiltshire SP4 0JQ, UK

3 Royal Armouries, Armouries Drive, Leeds LS10 1LT, UK
Buff-coats have been described as 'an oil-tanned, leather garment, typically with thigh to knee-length skirts used in place of, or in conjunction with, plate armour' [11]. Oiltanned refers to the buff leather production technique which was based upon the oxidation of marine animal or fish oils [13]. Although buffalo hide may have given the garment its name, cattle and deer hides were more commonly used [11]. In the seventeenth century, buff-coats were one of the most widely worn forms of body-protection amongst the cavalry of many European nations [11].

Analysis of the Littlecote collection buff-coats suggested that they were individually tailored for the men wearing them [20]. Despite their relatively widespread use amongst the cavalry, use as a protective garment during the English Civil Wars, their effectiveness as a protective garment is not known [11]. Buff-coats were commonly worn over civilian clothing (linen shirt and wool waistcoat) during the English Civil War as the use of uniforms was not common [21].

The musketeers of the English Civil War typically carried a matchlock musket, with the 12-bore musket being the most common calibre [15]. The projectiles fired using muskets were typically lead spheres and were accelerated by burning gunpowder (black powder) within the barrel of the weapon and behind the projectile. Black powder is a pyrotechnic mixture containing a fuel (charcoal and sulphur) and an oxidizer 
(potassium nitrate) [1]. The rapid burning of black powder produces large quantities of gases that create a high pressure within the confined space of the barrel accelerating the projectile along and out of the barrel.

The Royal Armouries requested that the ballistic protective properties of a one type of clothing system (linen shirt, wool waistcoat and buff-coat) worn during the English Civil War be estimated and that the behind clothing wounding be considered to add to the international literature on this topic.

\section{Materials and method}

\section{Leather, wool and linen}

In the current work, oil-tanned leather (Clayton of Chesterfield, UK), plain-woven wool fabric (Historical Management Associates Ltd., Bristol, UK) and plain-woven linen fabric (The Tudor Tailor, Nottingham, UK) were used to represent buff-coat, wool waistcoat and linen shirt clothing layers. The linen was washed before use according to ISO 6330:2001 and flat dried to Procedure C [4]. The thicknesses of the leather, wool and linen were measured using a Mitutoyo Thickness Gauge Model ID-C1012MB with a tolerance of \pm $0.02 \mathrm{~mm}$. Leather thickness was determined according to ISO 2589:2016 [7] whilst density was calculated according to ISO 2420:2017 [6]. Wool and linen fabric mass per unit area was calculated according to BS 2471:2005 [5]. Masses of specimens were measured using an Oxford A2204 scale with a tolerance of $\pm 1 \mathrm{mg}$. Specimens for testing were cut $250 \times$ $250 \mathrm{~mm}$.

\section{Gelatine}

Gelatine blocks ( $10 \%$ by mass and conditioned to $4{ }^{\circ} \mathrm{C}$ ) are commonly used as a tissue simulant in wound ballistic experiments [10]. Mabbott [16] suggested that $10 \%$ (by mass) gelatine conditioned to $4{ }^{\circ} \mathrm{C}$ closely replicates the thorax when considering penetrations for specific projectiles. Six gelatine blocks $(250 \times 250 \times 500 \mathrm{~mm})$ were made using Gelita ${ }^{\circledR}$ Ballistic 3 gelatine (Lot 073650) in aluminium containers and conditioned for $36 \mathrm{~h}$ at $4{ }^{\circ} \mathrm{C}$ [16]. The blocks were calibrated prior to ballistic testing by firing a $5.5-\mathrm{mm}$ diameter steel ball bearing (Atlas Ball \& Bearing Company, Walsall, Batch Number 13103003) in to the top right-hand corner of each block using a gas-gun ('Gas-gun' section). Ballistic impacts were recorded using a Phantom V1212 high-speed camera (12,000 frames per second). Impact velocity of the ball bearing was calculated from the high-speed video of each impact and along with the depth of penetration (DoP) into the block compared with prior calibration data [16]. After calibration, each block was cut in half $(250 \times 250 \times 250 \mathrm{~mm})$ for use in the ballistic testing.

\section{Projectiles}

Firth and Dowen suggested that 12-bore musket balls were the most common projectile used during the English Civil War $[12,14]$, and this calibre was selected as a representative projectile for the current work. Twelve lead projectiles were cast using a spherical 12-bore musket ball split mould (Fig. 1). Projectile diameter, mass, elemental analysis (Hitachi SU3500 Scanning Electron Microscope fitted with an Ametek Octane Plus Microscope and using TEAM (Texture \& Elemental Analytical Microscopy)) and Vickers hardness (Indentec Hardness Tester, Model HWDM-7) were measured and compared with data for historical specimens provided by one of the authors $(\mathrm{KD})$.

\section{Gas-gun}

Projectiles (ball bearings and lead spheres) were fired in purpose designed sabots using a gas-gun system (Fig. 2). Projectile velocity was adjusted by altering the nitrogen pressure used to operate the gas-gun (Annex). To ensure that only the projectile impacted the target, a sabot stripper was placed $820 \mathrm{~mm}$ from the end of the gas-gun barrel.

\section{Ballistic testing}

Clothing layer specimens (leather, wool fabric, linen) were mounted on the anterior surface of a block of gelatine using dress-makers pins in each corner (Fig. 3). The leather formed the impact face of the resulting target which was impacted centrally with a single 12-bore lead sphere at varying velocities. Each impact was recorded using a high-speed video as described in the 'Gelatine' section. The ballistic performance of the

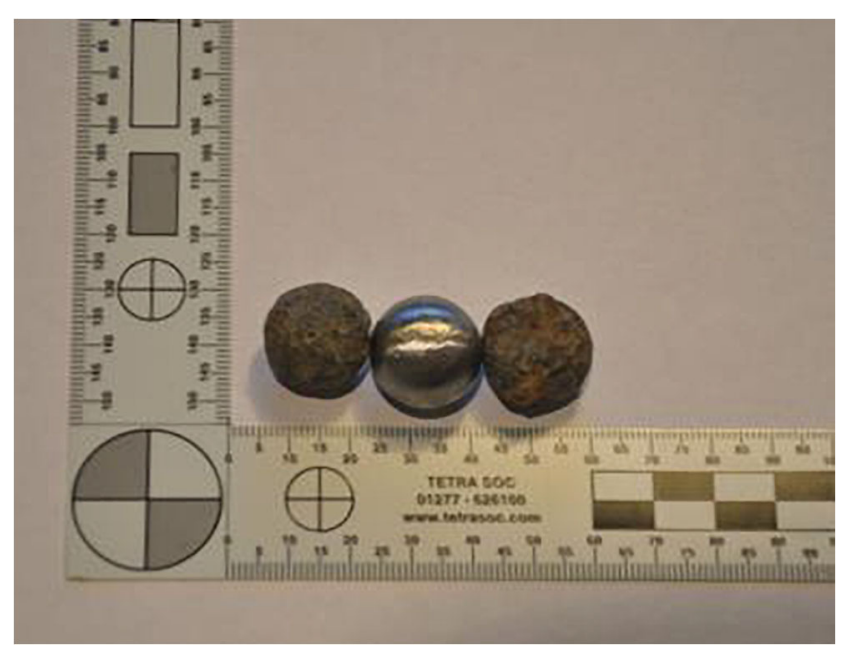

Fig. 1 Modern cast test projectile between two historical examples recovered from the Thames Foreshore 


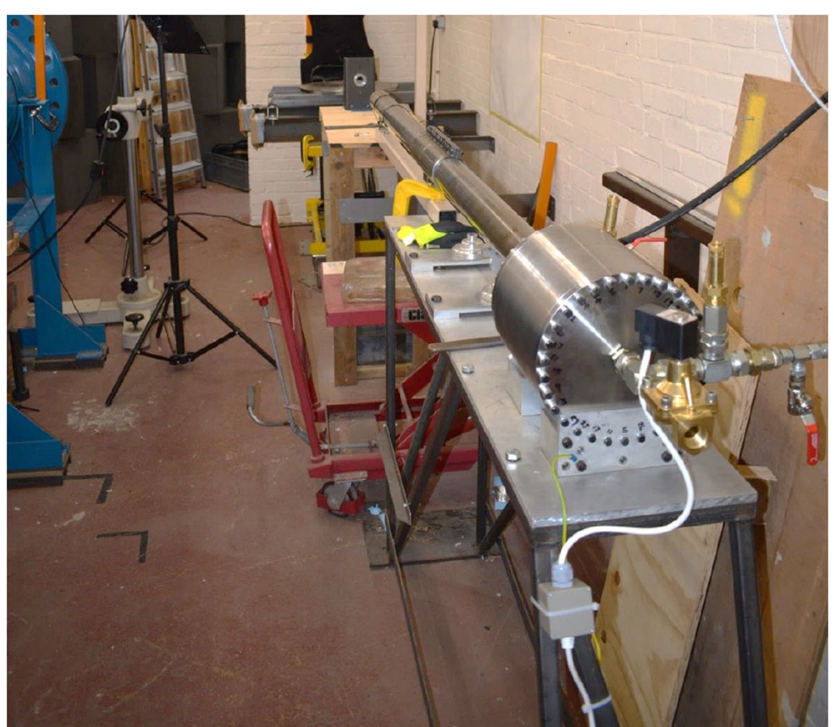

Fig. 2 Shrivenham gas-gun

clothing system, estimated $V_{50}$, was calculated with reference to AEP-2920(A) [19]. Twelve shots were fired in total and a single six-shot $V_{50}$ was calculated from the three fastest non-perforating impacts and the three slowest perforating impacts with $a \leq 40 \mathrm{~m} / \mathrm{s}$ spread across all velocities [19]. Ideally multiple $V_{50}$ data would be obtained and the $V_{50}$ expressed as a mean of these results with an associated standard deviation. However, in this work, the amount of material representative of the clothing system was limited and therefore the $V_{50}$ calculated should be considered indicative of the protective performance of the clothing system. The distance at which the projectile would decelerate from the muzzle velocity to the estimated $V_{50}$ was calculated and compared with known effective engagement distances. Previously published bounce-and-roll data for 12-bore lead spheres [18] was also considered so that the protective capabilities from ricochet could be considered. Finally, probable wounding effects were considered by examination of the high-speed video and post-testing dissection of the gelatine blocks.

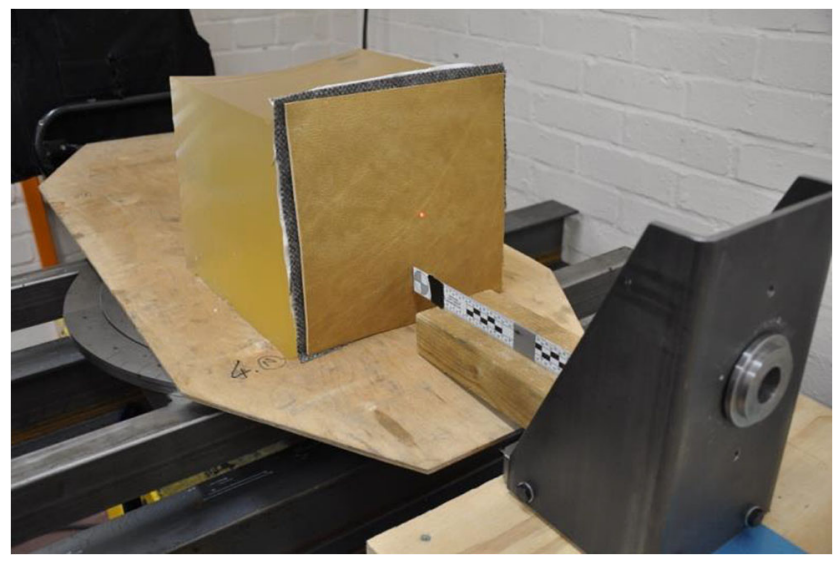

Fig. 3 Configuration of target materials

\section{Results and discussion}

\section{Clothing layers}

The physical properties of the clothing layers are given in Table 1. As expected, the leather was the thickest and heaviest, and the linen was the thinnest and lightest. The variability of the leather was smaller than the other two layers due to the nature of the processing of this material (i.e. trimmed). The thickness of the leather compared favourably with thickness data for buff-coats from The Royal Armouries Collection which varied from 1.52 to $5.33 \mathrm{~mm}($ mean $=3.56 \mathrm{~mm})$ [23].

\section{Lead spherical projectiles}

The cast lead spheres had a mean diameter of $18.55 \mathrm{~mm}(\mathrm{SD}=$ $0.12 \mathrm{~mm})$, a mean mass of $36.1 \mathrm{~g}(\mathrm{SD}=0.18 \mathrm{~g})$ and a mean Vickers hardness of 24.6 Vickers (SD $=0.69$ Vickers). The modern projectiles were a lead/antimony alloy. These properties can be compared with data for a historical example provided by KD. The historical projectile had a mass of $37.2 \mathrm{~g}$, so slightly heavier than the modern spheres. No measurement of the outside diameter of the historical projectile was undertaken due to the formation of a corrosion layer as the measured dimension would describe what the dimension of projectile plus corrosion is and not its original dimensions when cast.

The alloying of the lead with antimony resulted in a harder projectile; the historical projectile had a hardness of 5.4 Vickers. Some information regarding historical musket balls is also available in the literature and compares favourably with the modern spheres manufactured for the current work. For example, a musket ball from the Battle of Marston Moor had a hardness of 6.32 Vickers and was $99.7 \%$ lead; musket balls recovered from the Battle of Edgehill had a mean diameter of $18.51 \mathrm{~mm}$ and a mean mass of $37.9 \mathrm{~g} \mathrm{[26].}$

\section{Gelatine calibration}

The mean impact velocity of the calibration shots was $190.8 \mathrm{~m} / \mathrm{s}(\mathrm{SD}=2.4 \mathrm{~m} / \mathrm{s})$ and the mean DoP was $150.5 \mathrm{~mm}$ $(\mathrm{SD}=11.0 \mathrm{~mm})$. This data compared favourably with previous calibration data [16] providing confidence in the quality of the prepared gelatine blocks both within the batch used, but also when compared with previous data (Fig. 4).

\section{Ballistic testing}

Using the ballistic test data (Table 2), a single six-shot 12-bore lead sphere estimated $V_{50}$ of $102 \mathrm{~m} / \mathrm{s}(\mathrm{SD}=7.5 \mathrm{~m} / \mathrm{s})$ was calculated. This suggests that in $50 \%$ of cases a 12-bore lead sphere impacting the target at a velocity of $102 \mathrm{~m} / \mathrm{s}$ would perforate the target. 
Table 1 Physical properties of clothing layers

\begin{tabular}{llllll}
\hline Clothing layer & \multicolumn{2}{l}{ Thickness $(\mathrm{mm})$} & & \multicolumn{2}{l}{ Leather density $\left(\mathrm{g} / \mathrm{m}^{3}\right) /$ fabric mass per unit area $\left(\mathrm{g} / \mathrm{m}^{2}\right)$} \\
\cline { 2 - 3 } & Mean & SD & & Mean & SD \\
\hline Leather & 3.36 & 0.28 & & 0.98 & 0.07 \\
Linen & 0.38 & 0.04 & & 182.62 & 2.12 \\
Wool & 2.01 & 0.04 & & 367.19 & 2.22 \\
\hline
\end{tabular}

\section{Deceleration of a musket ball in air}

Understanding the distance from the end of the weapon system's muzzle that a musket ball would need to travel to have a velocity of $102 \mathrm{~m} / \mathrm{s}$ would allow comment on the effectiveness of the clothing system at Civil War engagement distances. The muzzle velocity of a seventeenth century 12 bore musket has been estimated as $457 \mathrm{~m} / \mathrm{s}$ [18]. Allen [2] published formulae which are valid between Mach 2 $(681 \mathrm{~m} / \mathrm{s})$ and Mach $0.2(68 \mathrm{~m} / \mathrm{s})$ to relate velocity to distance for spherical projectiles. The drag coefficient for a sphere changes as the projectile decelerates through the speed of sound (Fig. 5); therefore, three steps need to be considered (i) deceleration from $457 \mathrm{~m} / \mathrm{s}$ to Mach $1.2(408 \mathrm{~m} / \mathrm{s})$; (ii) Mach 1.2 to Mach $0.7(238 \mathrm{~m} / \mathrm{s})$ and (iii) Mach 0.7 to $102 \mathrm{~m} / \mathrm{s}$ [2].

To calculate the velocity at any distance between the firing point, when muzzle velocity is above Mach 1.2 , and the distance at which the projectile decelerates to Mach $1.2\left(x_{1}\right)$ :

$v=\frac{0.92 M_{0} v_{\mathrm{s}}}{\left(0.92+0.0375 M_{0}\right) \exp \left(\frac{0.69 x}{k_{\mathrm{z}}}\right)-0.0375 M_{0}}$

where $v$ is velocity of the projectile $(\mathrm{m} / \mathrm{s})$,

$v_{\mathrm{s}}$ is the velocity of sound $(\mathrm{m} / \mathrm{s})$,

Fig. 4 Calibration data compared with previous data $x \quad$ is the distance that the projectile has travelled (m) and $M_{0}$ is the muzzle velocity of the projectile expressed as a Mach ratio.

$k_{\mathrm{z}} \quad$ is a scaling factor with the same units as distance $\mathrm{x}$ (i.e. $m$ ) and is defined as:

$k_{\mathrm{z}}=\frac{D \rho_{\mathrm{p}}}{\rho_{\mathrm{a}}}$

where $D$ is the diameter of the projectile $(18.5 \mathrm{~mm})$,

$\rho_{\mathrm{p}} \quad$ is the density of the projectile $\left(10.9 \mathrm{~g} / \mathrm{cm}^{3}\right)$ and

$\rho_{\mathrm{a}}$ is the density of air at $20^{\circ} \mathrm{C}\left(1.20 \times 10^{-3} \mathrm{~g} / \mathrm{cm}^{3}\right)$.

Therefore, $k_{\mathrm{z}}$ is $168.04 \mathrm{~m}$.

For a projectile with an initial velocity greater than Mach 1.2, the distance at which it will have decelerated to Mach 1.2 $\left(x_{1}\right)$ is obtained by using the following equation:

$x_{1}=1.44298 k_{\mathrm{z}} \ln \left(\frac{0.80417 M_{0}}{0.92+0.0375 M_{0}}\right)$

For a 12-bore musket ball with a muzzle velocity of $457 \mathrm{~m} / \mathrm{s}$ (Mach 1.3), it will decelerate to Mach 1.2 $(412.8 \mathrm{~m} / \mathrm{s})$ after a distance of $23.1 \mathrm{~m}$.

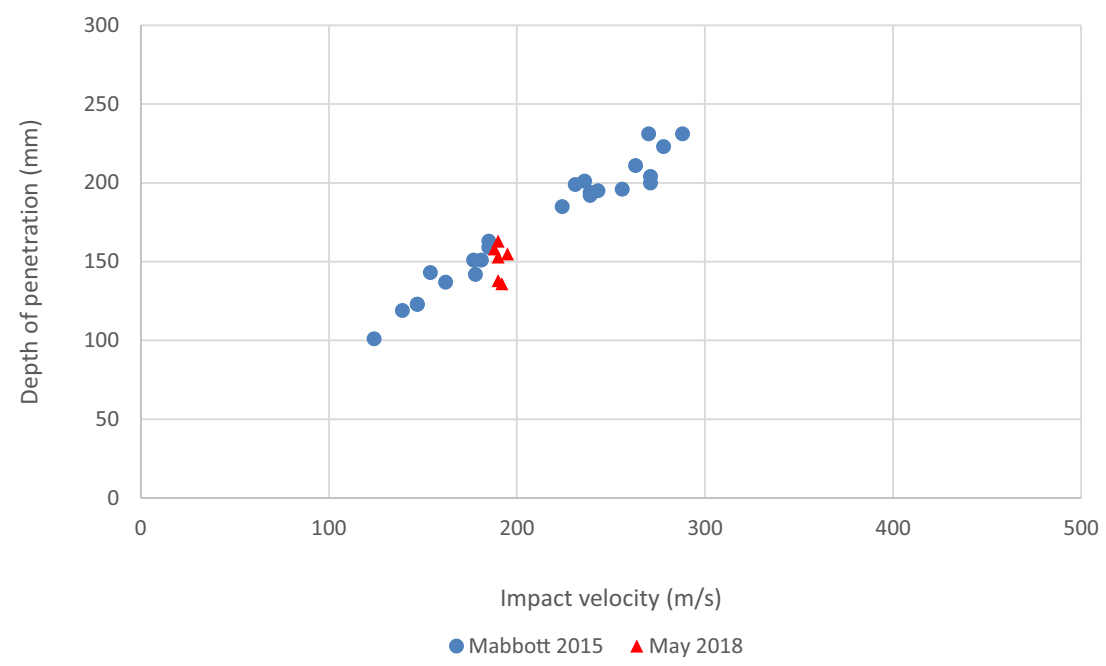


Table 2 Ballistic testing results

\begin{tabular}{lll}
\hline Shot & Non-perforation $(\mathrm{m} / \mathrm{s})$ & Perforation $(\mathrm{m} / \mathrm{s})$ \\
\hline 1 & 102 & \\
2 & 111 & \\
3 & & 128 \\
4 & & 120 \\
5 & & 117 \\
6 & & 115 \\
7 & & 112 \\
8 & & 109 \\
9 & & 105 \\
10 & 83 & 97 \\
11 & 91 & \\
12 & & \\
\hline
\end{tabular}

To determine the distance at which it would decelerate to Mach $0.7\left(x_{2}\right)$, Allen used the following equation:

$x_{2}=x_{1}+1.05173 k_{\mathrm{z}}$

Therefore, the distance from the firing position at which the 12-bore projectile would have decelerated to Mach 0.7 $(240.8 \mathrm{~m} / \mathrm{s})$ is $199.9 \mathrm{~m}$.

For the final phase deceleration profile:

$$
v=\frac{0.2926 v_{s}}{0.495 \exp \left(\frac{0.3135\left(x-x_{2}\right)}{k_{\mathrm{z}}}\right)-0.077}
$$

The equation can be re-arranged to solve for a distance $(x)$ given a known velocity.

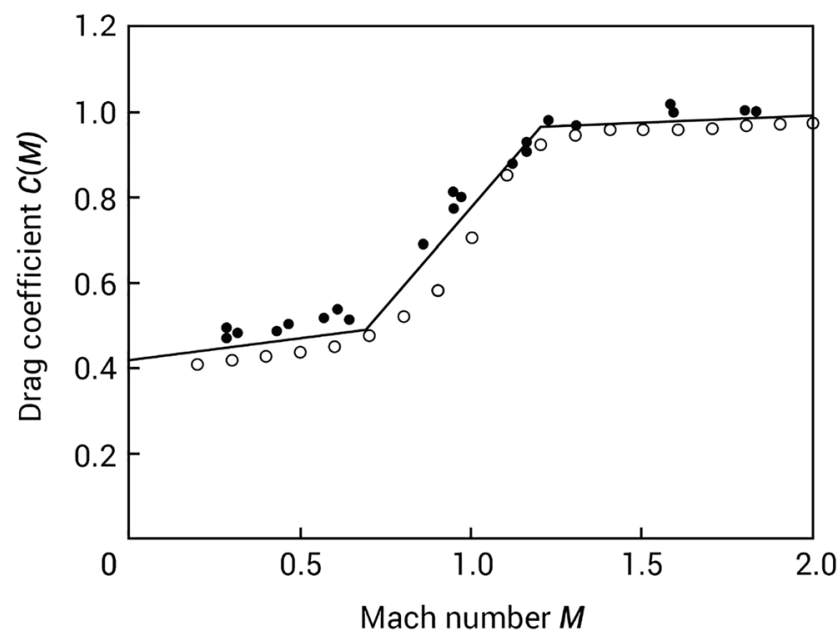

Fig. 5 Mean drag coefficient versus Mach number for Reynolds number 10,000 (open points) and 9/16" spheres (closed points). Adapted from [2] $x=\frac{k_{\mathrm{z}}}{0.3135}\left\{\ln \left(\frac{\frac{0.2926 v_{s}}{v}+0.077}{0.495}\right)\right\}+x_{2}$

Therefore, the $18.5-\mathrm{mm}$ diameter musket ball will decelerate from 457 to $102.5 \mathrm{~m} / \mathrm{s}$ in approximately $607 \mathrm{~m}$. Typical engagement distances during the English Civil Wars were much less than this, e.g. at the 2nd Battle of Newbury, Royalist Forces were ordered not to give fire until they came within a pike's length of the enemy $(\sim 5 \mathrm{~m})$ [21]. Therefore, the clothing system would not have protected the wearer from a 12-bore musket ball impacting a person on a direct trajectory from the firing weapon at engagement distances of the period.

\section{Protection from ricochet}

Reports from the Battle of Rathconnel discuss spent bullets (ricochets and bounces) hitting officers at close quarters with the enemy and failing to inflict penetrating injuries [21]. Clearly, the protective equipment worn was of some use against the battlefield threats of the day. Miller's live-firing experiments recorded initial flight distances of between 153 and $203 \mathrm{~m}$ before impacting the ground for the first time [18]. In some tests, following impact with the ground, the projectile skidded along the ground for a limited distance before bouncing back into the air (in some cases in excess of $2 \mathrm{~m}$ ) retaining $64 \%$ of the impact velocity; multiple bounces were recorded. The range of distances to the rounds' final resting positions ranged from 288 to $402 \mathrm{~m}$. This suggests that the clothing system could provide some protection from ricochet threats.

\section{Perforating wounding potential}

Shots that perforated the clothing system also perforated the gelatine block (Fig. 6). Human anthropometric data from 1981 for the British male thorax (19 to 45 years) suggests a 50th percentile chest depth of $240 \mathrm{~mm}$ [22]. Therefore, the perforating shots were likely to significantly penetrate the thorax of the wearer of the clothing system, although the target contained no bony structures.

Wiseman, writing 1705, commented that "wounds made by gun-shot are the most complicate sort of wounds that can be inflicted' ([25], p. 385). He also commented '...for the Bullet pierceth not any Part without carrying Rags along with it, which corrupt in the Wound and make Apostemations, occasioning a prolonging the Cure...Nay, while any of the Rags remain in the Wound, it will never cure ([25], p. 387).' Evidence of clothing layer fabric debris inside the wound tract was observed during the experiments conducted (Fig. 7) and has been reported in many modern wound ballistic studies. Such debris typically requires removal increasing the level of surgical intervention. 
Fig. 6 Typical example of a projectile perforating the gelatine

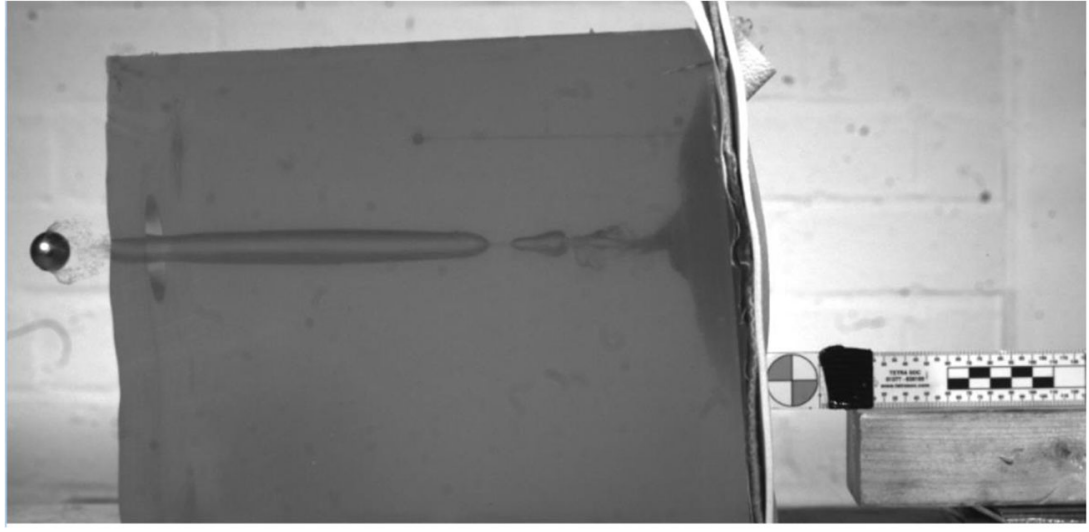

\section{Non-perforating wounding potential}

Behind armour blunt trauma (BABT) is '...the nonpenetrating injury resulting from the rapid deformation of armours covering the body' [8]. Test standards for modern body armour are designed to prevent serious BABT injuries; bruising and damage to the ribs are relatively common [9]. Such injuries were familiar to Wiseman who wrote:

And this hath happened to many in Service, who have been brought to me as mortally wounded, whereas upon search, I have found the impression only upon the greasy leather Jerkin, or their bellies black and a little scratch by the bullet. Yet these are even subject to Tumour...In others the Skin, and the Flesh under it, is sometimes wounded, and no farther. These are by us called Wounds of the Belly, not penetrating and are cured as Gun-shot Wounds in Fleshy parts...For the

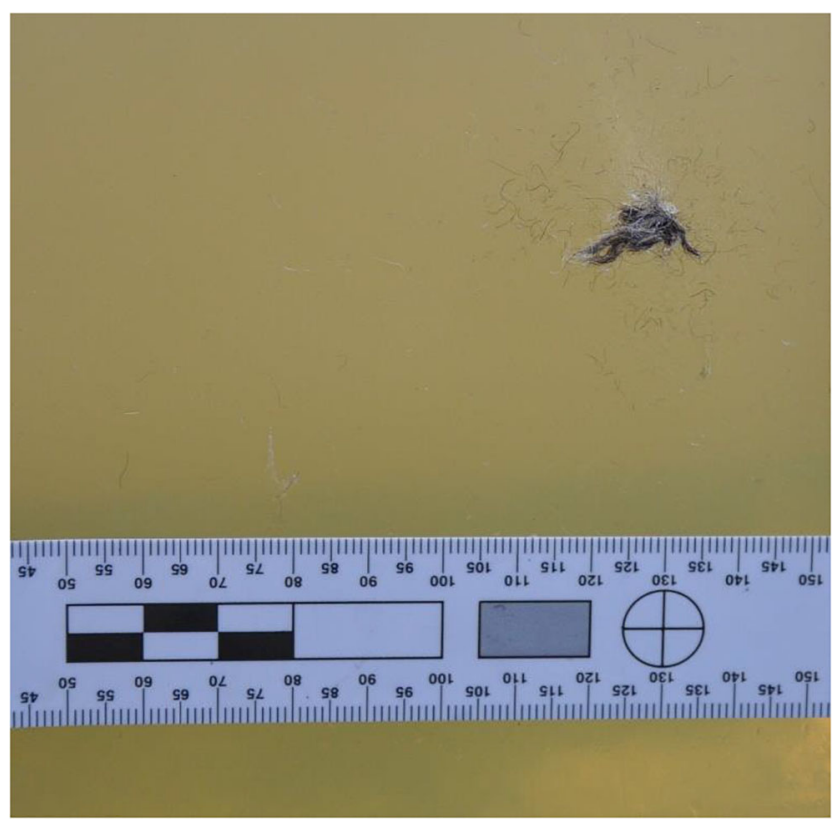

Fig. 7 Typical example of textile debris deposited in the gelatine due to a penetrating shot bullet is for the most part carried with such force, that it not only wounds the fleshy parts but also pierces the Peritoneum, hurting most an end the Internals; it being indeed impossible that the Bullet piercing the Parts containing should miss the parts contained, which are soft and tender...I have seen sometimes in the Wars a Soldier shot scarce to the Peritoneum yet the Contusion hath been so great, that the Peritoneum hath come off upon Digestion: In which case the Bowels commonly suffer under severe Colicks, and there ariseth Difficulty of breathing ([25], p. 408).

Figure 8 is extracted from a high-speed video of a non-perforating impact of a 12-bore lead sphere impacting the clothing layers mounted on a $10 \%$ (by mass) gelatine block at $111 \mathrm{~m} / \mathrm{s}$ and shows the deformation behind the clothing layers into the gelatine. The depth of the deformation is known as the back-face signature (BFS) and in the four non-perforating impacts recorded for the 12-bore lead spheres were $50 \mathrm{~mm}, 54 \mathrm{~mm}, 60 \mathrm{~mm}$ and $62 \mathrm{~mm}$. Similar images and BFS data have been reported for modern body armour mounted on gelatine blocks [17]. The armour packs tested by Malbon et al. [17] were to the approved standard for police

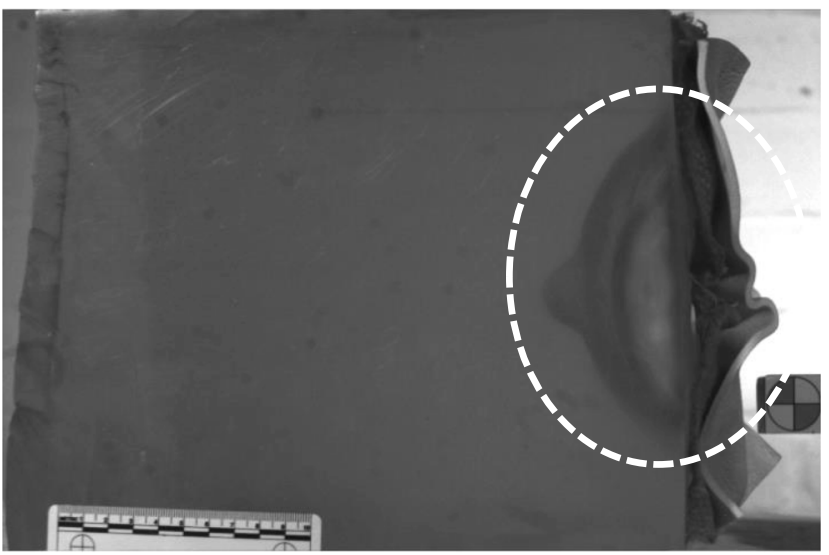

Fig. 8 Maximum deformation into a gelatine block of a non-perforating impact (highlighted) 


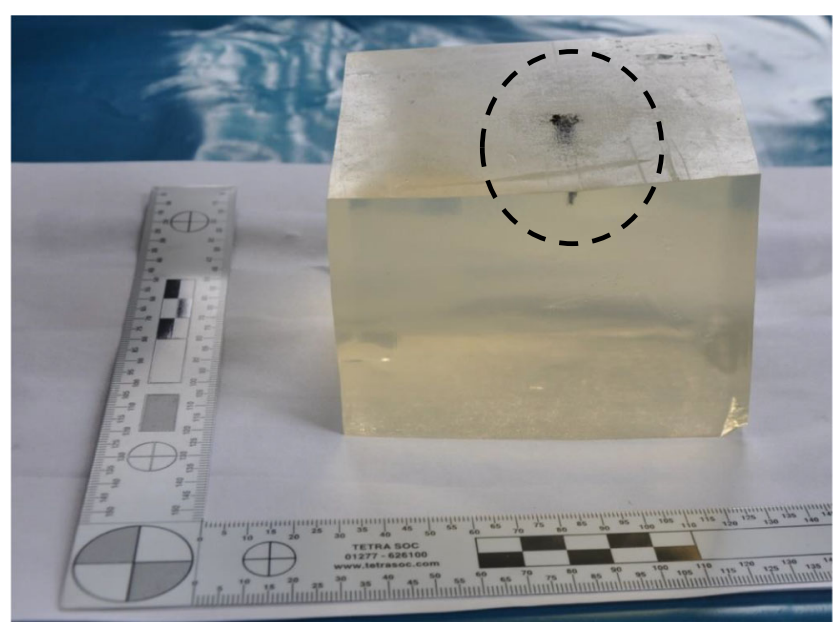

Fig. 9 Pencilling wound pattern from non-penetrating shot highlighted by ink (highlighted)

body armour in the UK, suggesting that the 12-bore impacts would have led to injuries similar to those seen in the modern scenario, i.e. bruises and damaged ribs as reported by Wiseman [25].

Examination of the clothing layers identified permanent deformation that matched the diameter of the 12-bore lead sphere (Fig. 9). Transfer of the linen weave pattern to the gelatine block was also noted over the diameter of the elastic deformation observed in Fig. 10.

Permanent damage of the gelatine block was noted for the non-perforating impacts. This damage was approximately 4$\mathrm{mm}$ wide and $15-\mathrm{mm}$ deep channel; this can be considered to be an example of pencilling which is defined as 'a narrow indentation of soft body armour into the ballistic backing material in instances where the armour has not been perforated' (Reference 2017 Body armour standard on gov.uk). This is similar to Wiseman's description of wounds where 'the Skin, and the Flesh under it, is sometimes wounded, and no farther' [25]. Pencilling is of interest in modern body armour testing and if observed is specifically reported.

\section{Conclusions}

One type of clothing system, more common amongst cavalrymen than infantrymen, was the linen shirt, wool waistcoat and buff-coat. The ballistic protective performance $\left(V_{50}\right)$ of this clothing system mounted on a tissue simulant was estimated as $102 \mathrm{~m} / \mathrm{s}$ for the projectiles used. However, it should be noted that the modern projectiles were harder than historical projectiles; therefore, it is likely that the clothing system would have provided a greater level of protection from historical projectiles. The distance which the 12-bore lead projectile would travel from the end of the weapon's muzzle to reach this velocity was calculated as $607 \mathrm{~m} / \mathrm{s}$. Given engagement distances could be as short as
$5 \mathrm{~m}$, it is unlikely that the clothing system would have provided protection from a direct hit. However, when considering published ricochet data and historical accounts, it is possible that the wearer would have been protected by the clothing system. Both non-perforating and perforating shots resulted in damage to the tissue simulant commensurate with modern hand-gun injuries and historical accounts.

Acknowledgements This work forms part of Commander Brian May's MSc which is available from the Barrington Library, Cranfield University, UK. The authors would like to thank:

- The Royal Armouries, Leeds, UK for provision of the leather, fabrics and historical musket balls used in this work.

- Mr. David Miller, Mr. Adrian Mustey, Dr. Jon Painter and Surg Lt Cdr Tom Stevenson for their assistance with experimental work.

Funding information The authors would like to thank the Canadian Department of National Defence for financial support.

\section{Compliance with ethical standards}

Conflict of interest The authors declare that they have no conflicts of interest.

Ethical approval Ethical approval for this work was granted through Cranfield University Research Ethics System (CURES/4945/2018).

Informed consent All authors agree to the publication of this manuscript. No informed consent was required throughout this manuscript

\section{Annex. Pressure vs velocity of surrogate musket rounds}

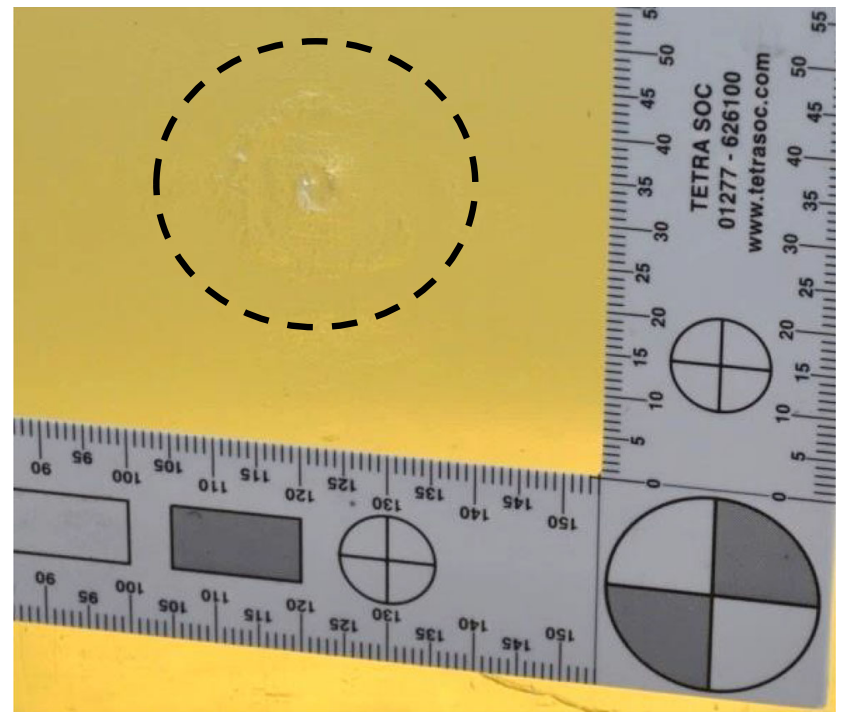

Fig. 10 Non-penetrating shot showing the image of the muslin material impressed into the gelatine material (highlighted) 
Open Access This article is licensed under a Creative Commons Attribution 4.0 International License, which permits use, sharing, adaptation, distribution and reproduction in any medium or format, as long as you give appropriate credit to the original author(s) and the source, provide a link to the Creative Commons licence, and indicate if changes were made. The images or other third party material in this article are included in the article's Creative Commons licence, unless indicated otherwise in a credit line to the material. If material is not included in the article's Creative Commons licence and your intended use is not permitted by statutory regulation or exceeds the permitted use, you will need to obtain permission directly from the copyright holder. To view a copy of this licence, visit http://creativecommons.org/licenses/by/4.0/.

\section{References}

1. Akhavan J (2006) The chemistry of explosives, 2nd edn. Royal Society of Chemistry, Dorchester

2. Allen EJ (2018) Approximate ballistics formulas for spherical pellets in free flight. Defence Technol 14(1):1-11. https://doi.org/10. 1016/j.dt.2017.11.004

3. Anon (1985). 'Tower of London takes on new name and big project', The Arms Collecting Newsletter, 2(November), S-5

4. British Standards. (2001). BS EN ISO 6330:2001 textiles - domestic washing and drying procedures for textile testing. London

5. British Standards. (2005). BS EN ISO 2471:2005 textiles - woven fabrics - determination of mass per unit length and mass per unit area, 3

6. British Standards. (2015). Draft BS EN ISO 2420 leather - physical and mechanical tests - determination of apparent density and mass per unit area, 44(0)

7. British Standards. (2016). BS EN ISO 2589: 2016 BSI standards publication leather - physical and mechanical tests - determination of thickness. London

8. Cannon L (2001) Behind armour blunt trauma - an emerging problem. Journal of the Royal Army Medical Corps, 147(MARCH 2001), 87-96. https://doi.org/10.1136/jramc-147-01-09

9. Carr DJ, Horsfall I, Malbon C (2016) Is behind armour blunt trauma a real threat to users of body armour? A systematic review. J R Army Med Corps 162(1):8-11. https://doi.org/10.1136/jramc2013-000161
10. Carr DJ, Stevenson T, Mahoney PF (2018) The use of gelatine in wound ballistics research. Int J Legal Med 132:1659-1664

11. Dowen K (2015) The seventeenth century buff-coat. J Arrms Armour Soc 21(5):157-188

12. Dowen K (2019). Arms and armour of the English civil wars. Royal Armouries

13. Dowen $\mathrm{K}$ et al (2017) Leather in warfare: attack, defence and the unexpected. (Q. Mould, Ed.), 1st edn. Martyn Lawrence, Leeds

14. Firth C (1902) CromwArmy: a history of the English ell's Army: a history of the English soldier during the civil wars, the commonwealth and the protectorate. Methuen \& Co, London

15. Foard, G. (2008). Integrating documentary and archaeological evidence in the investigation of battles : a case study from seventeenthcentury England. University of East Anglia

16. Mabbott, A. J. (2015). The overmatching of UK police body armour. $\mathrm{PhD}$ thesis. Cranfield University, UK

17. Malbon, C., Carr, D.J. and Mauzac O. 2017. Comparison of backing materials used in the testing of body armour. In Proceedings of International Symposium on Ballistics 11-15 September. Long Beach

18. Miller DP, Allsop D, Carr DJ (2019) The ballistics of $17^{\text {th }}$ century musket balls. J Confl Archaeol 14:25-36

19. NATO. (2015). AEP-2920(A) (V1) - procedures for the evaluation and classification of personal armour - bullet and fragmentation threats. Brussels

20. Parnell G (2012) The artillery train sent to New England in 1664. Man At Arms Gun Sword Collector 34(5):24-32

21. Peachey S (2016) The soldier's life in the English civil war, 1st edn. Stuart Press, Bristol

22. Pheasant S (2005) Bodyspace - anthropometry, ergonomics and design, 3rd edn. Taylor and Francis, London

23. Richardson T (1988) The buff-coats at Littlecote House. Can J Arms Collect 26(1):25-31

24. Richardson, T and Rimer, G. (2019). Littlecote: the English civil war armoury. Royal Armouries

25. Wiseman R (1705) Eight chirurgical treatises (fourth). Benjamin Tooke and John Meredith, London

26. Harkins S (2006) The application of modern forensic techniques to battlefield archaeology. No. 8 Forensic Engineering and Science course MSc Thesis. Cranfield University.

Publisher's note Springer Nature remains neutral with regard to jurisdictional claims in published maps and institutional affiliations. 